\title{
Trace Element and Stable Isotope Analyses of Deep Sea Fish from the Sulu Sea, Philippines
}

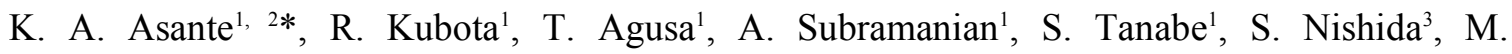 \\ Yamaguchi $^{3}$, K. Suetsugu ${ }^{3}$, S. Ohta ${ }^{3}$ and H. Yeh $^{4}$ \\ ${ }^{1}$ Center for Marine Environmental Studies (CMES), Ehime University, Bunkyo-Cho 2-5, \\ Matsuyama, Ehime, 790-8577, Japan \\ ${ }^{2}$ CSIR-Water Research Institute, P. O. Box AH 38, Achimota, Accra, Ghana \\ ${ }^{3}$ Ocean Research Institute, University of Tokyo, Minamidai 1-15-1, Nakano, Tokyo, 164-8639, \\ Japan; ${ }^{4}$ Academic Sinica, Taiwan \\ *Corresponding author; E-mail: kaasante@chemist.com
}

\begin{abstract}
Thirty-five deep sea fishes belonging to 22 species and one unidentified specimen obtained from the Sulu Sea, located in the southwestern area of the Philippines were analyzed in the late 2002, for 23 trace elements using ICP-MS, HGAAS and CV-AAS. Predominant accumulation of strontium ( $\mathrm{Sr}$ ) was observed in all the samples. This stems from the fact that the whole body of fish was homogenized since Sr is known to accumulate in bones and hard tissues. Mercury concentrations in all the 36 samples were below the detection limit. Cadmium concentrations were generally below 1 $\mu \mathrm{g} / \mathrm{g}$ dry weight (dw) except in Pterygotrigla spp. $(4.29 \mu \mathrm{g} / \mathrm{g} \mathrm{dw})$ and Sternoptyx pseudodiaphana $(2.89 \mu \mathrm{g} / \mathrm{g} \mathrm{dw})$. Concentrations of $\mathrm{Pb}$ were predominantly low with about $90 \%$ of the specimens having less than $1 \mu \mathrm{g} / \mathrm{g} \mathrm{dw}$. In general, concentrations of $\mathrm{Sr}, \mathrm{Zn}, \mathrm{Cu}, \mathrm{Se}$ and $\mathrm{Cd}$ appeared to increase with increasing depth of occurrence of the species. Manganese, $\mathrm{Tl}, \mathrm{Pb}, \mathrm{Bi}, \mathrm{In}, \mathrm{Cs}$ and As showed significant positive correlation $(p<0.05)$ with $\delta^{15} \mathrm{~N}$, suggesting that these elements were biomagnified. To our knowledge, this is the first study reporting $\mathrm{Tl}$ biomagnification in fish. Rubidium and $\mathrm{Cs}$ showed significant positive correlation with $\delta^{13} \mathrm{C}$, implying that $\mathrm{Rb}$ and $\mathrm{Cs}$ would originate from offshore waters as oceanic plankton has high $\delta^{13} \mathrm{C}$. Comparing results from this study to the dietary standards and guidelines for $\mathrm{Hg}, \mathrm{Pb}, \mathrm{Cu}$ and $\mathrm{Zn}$ in fish and shellfish of the Ministry of Agriculture, Fisheries and Food of the United Kingdom, these levels were not high to warrant concern if they were to be consumed by humans. However, $16.7 \%$ of the fish samples had high Cr levels when compared with the Hong Kong's safe limit of $4 \mu \mathrm{g} / \mathrm{g} \mathrm{dw}$ for $\mathrm{Cr}$ in sea food. This constitutes a health risk to humans, as $\mathrm{Cr}$ is potentially toxic.
\end{abstract}

\section{Introduction}

The deep sea is a vast area which remains largely unexplored, especially in terms of its biota (Ruhl \& Smith, 2004). Collectively the deep sea and its ecosystems are considered to be the sink and final reservoir for contaminants (Tatsukawa \& Tanabe, 1984). Pollution of marine ecosystems by trace elements is of global environmental concern. Elements in trace concentrations are normal constituents of marine organisms. At high levels they are potentially toxic and may disrupt biological activities of aquatic ecosystems. The ability of trace elements to be concentrated in the organs of marine organisms accounts for their toxicity and also poses a direct threat to both the aquatic biota and man (Watling, 1983).

Many deep sea species are long lived, with slow growth rates and are likely to reach maturity at a much more advanced age than commercial species from continental shelf areas (Gordon et al., 1995). They tend to feed at higher trophic levels than their shallow-water counterparts and, thus, could be exposed to higher levels of elements for longer periods hence the accumulation of trace elements could be greater (Gordon et al., 1995). A study by Mormede \& Davies (2001) revealed that trace elements such as cadmium, mercury, lead, copper and zinc were found in relatively high concentrations in some deep sea fish species (Nezumia aequalis, Lepidon eques and Raja fyllae) from the Rockall Trough, west of Scotland.

In contrast to the enormous amount of knowledge on trace element concentrations in near shore organisms, little is known about accumulation levels of trace elements in deep sea 
organisms (Cronin et al., 1998; Vas et al., 1993; Windom et al., 1987) and their species-specific accumulation profile. There is a paucity of study of these organisms to elucidate their accumulation levels. There is increasing interest in studying the degree of contamination of the deep sea environment. However, many studies do not typically examine the total body burden of trace elements in fish but only concentrations in muscle tissue were investigated, as from a human health perspective. This is, therefore, one of the very few studies that have dealt with the analyses of trace elements in whole fish from deep sea.

Stable isotope analysis has emerged as a powerful tool to trace diet as isotope ratios of a consumer are related to those of their preys (DeNiro \& Epstein, 1978, 1981). Carbon and nitrogen isotope values $\left(\delta^{13} \mathrm{C}\right.$ and $\left.\delta^{15} \mathrm{~N}\right)$ differ between organisms and their diets because of a slight selective retention of the heavier isotope and excretion of the lighter one. As a result, organisms have a higher ' value than their diet. Changes in ratios of stable isotopes of carbon and nitrogen have been used to elucidate trophic relationships within marine food webs (Hobson et al., 1997). For nitrogen, enrichment in ${ }^{15} \mathrm{~N}$ typically shows a stepwise increase with trophic level within a food chain with a trophic enrichment value of about 3\%o (Hobson \& Welch, 1992). Thus, carbon-13 value, rather than being a reliable indicator of the trophic level, is preferentially used to indicate relative contributions to the diet of different potential primary sources in a trophic network, indicating the aquatic $v s$. terrestrial, inshore $v s$. offshore, or pelagic $v s$. benthic contribution to food intake (Hobson et al., 1995; Dauby et al., 1998).

Trace elements are merely transferred through diet. Indeed, trace element levels found in marine organisms depend not only on the contamination of the environment but also on several other ecological or physiological factors among which the diet and trophic position are determining elements (Das et al., 2003). By using a combination of stable isotope and trace element analyses, one could compare the diet and position in the trophic web of predators.

Asia is the world's leading fish producer and accounts for over $63 \%$ of the total fish production (Briones et al., 2004). Fish forms an important part of Asian diets. In the Philippines, marine fisheries provide various economic and social benefits (Luna et al., 2004). In 2003, the sector produced 2.03 million tonnes of fish and invertebrates (BAS, 2004). Most people fish for personal consumption, and fish consumption is estimated at $30 \mathrm{~kg}$ per capita. There is no information on the contamination or baseline status of trace elements in water and fish from the Sulu Sea, despite that fish is an important component of the diet of Filipinos. It was deemed necessary to focus on trace element levels in deep sea fish from the Sulu Sea in an attempt to establish baseline levels and whether they meet the statutory levels recognized as safe for human consumption.

The aim of the study was to investigate and provide data on the concentrations of trace elements in fish species collected from deep water in the Sulu Sea in order to elucidate the accumulation characteristics. Stable carbon $\left(\delta^{13} \mathrm{C}\right)$ and nitrogen $\left(\delta^{15} \mathrm{~N}\right)$ isotopes analyses were used to evaluate the relationship between accumulation of trace elements and trophic levels in deep sea ecosystem.

\section{Materials and methods}

The Sulu Sea is located in the southwestern area of the Philippines (Fig. 1). It is separated from the South China Sea in the northeast by the Palawan Island and from the Celebes Sea in the southeast by a chain of islands known as Sulu Archipelago. The Sulu Sea, together with the Celebes Sea, constitutes the Sulu-Celebes Sea Large Marine Ecosystem (LME). It has an area of about $900,000 \mathrm{~km}^{2}$ and much of the LME has a depth greater than $3000 \mathrm{~m}$.

Some deep sea fishes were collected from the Sulu Sea (Fig. 1) and surrounding areas during November-December 2002, with either a mid-water trawl, a plankton net, or a beam trawl (for data collection see Nishida \& Gamo, 2004). Thirty-five specimens belonging to 22 species and 
one unidentified specimen were analyzed for trace elements. All the samples were kept in an ice box and transported to the environmental specimen bank (es-bank) at Ehime University, Japan and kept at $-20{ }^{\circ} \mathrm{C}$ until chemical analysis.

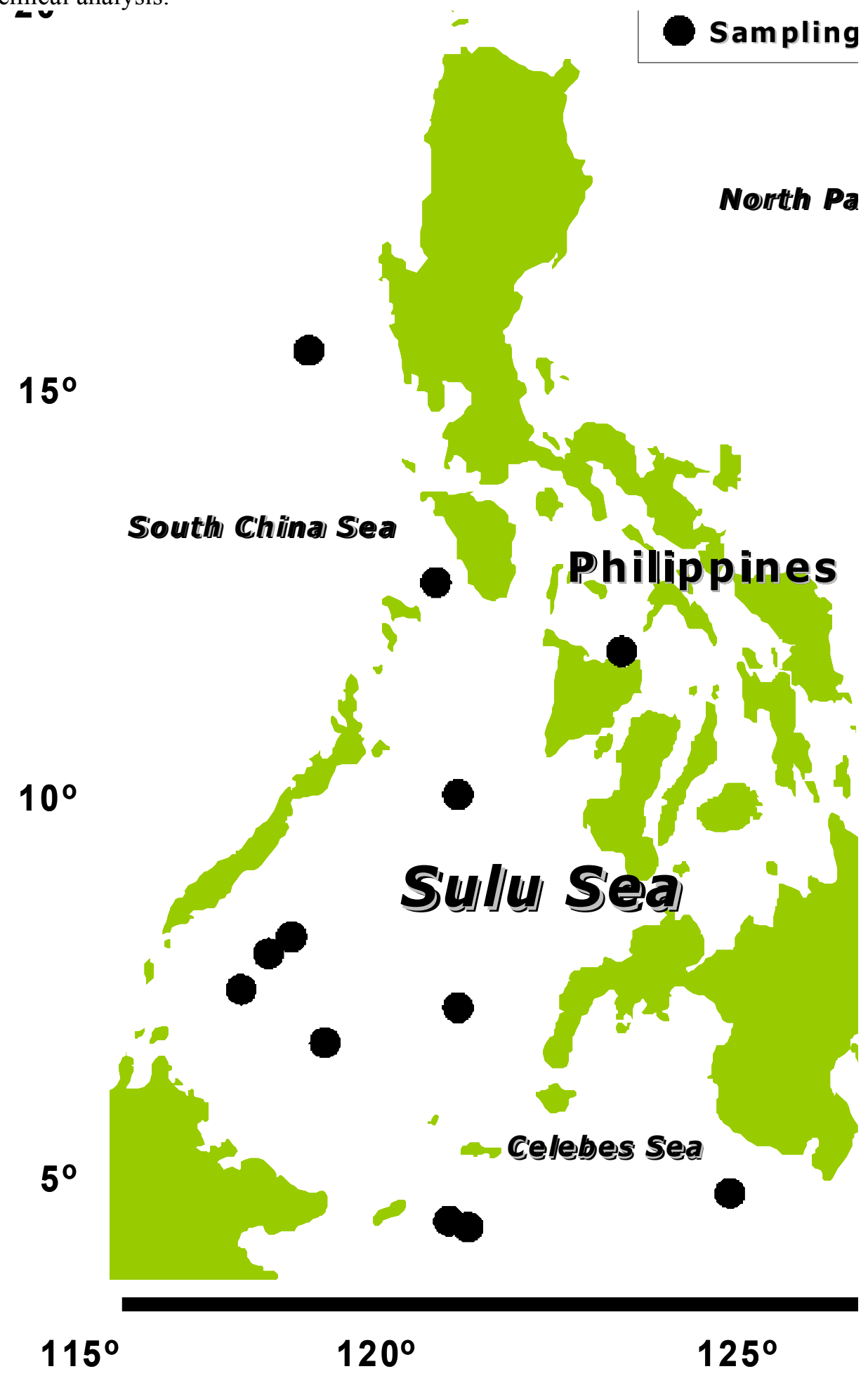


Fig. 1. Map of the Sulu Sea showing sampling locations

The whole bodies of the specimens of the same species were pooled and homogenized to prepare a composite sample. Where possible, the size ranges of fish have been provided (Table 1). The samples were dried at $80{ }^{\circ} \mathrm{C}$ for $12 \mathrm{~h}$ and about $0.2 \mathrm{~g}$ dry weight digested by microwave in the presence of concentrated nitric acid in Teflon vials. Concentrations of trace elements (V, Cr, Mn, Co, Cu, $\mathrm{Zn}, \mathrm{Ga}$, $\mathrm{Rb}, \mathrm{Sr}, \mathrm{Mo}, \mathrm{Ag}, \mathrm{Cd}, \mathrm{In}, \mathrm{Sn}, \mathrm{Sb}, \mathrm{Cs}, \mathrm{Ba}, \mathrm{Tl}, \mathrm{Pb}$ and $\mathrm{Bi}$ ) were measured by an inductively-coupled plasma mass spectrometer (ICP-MS, HP-4500, Hewlett-Packard, Avondale, PA, USA). Matrix effects and instrumental drift in the ICP-MS measurements were corrected by the internal standard method with indium as the internal standard. Concentrations of $\mathrm{Hg}$ and $\mathrm{Se}$ were determined by cold vapouratomic absorption spectrometry (CV-AAS, model HG-3000, Sanso, Tsukubu, Japan) and hydride generation-atomic absorption spectrometry (HG-AAS, HVG-1 hydride system, Shimadzu, Kyoto, Japan), respectively. For As determination, about $0.05 \mathrm{~g}$ dry weight of the samples were treated with acid mixture $\left(\mathrm{HNO}_{3}: \mathrm{HClO}_{4}: \mathrm{H}_{2} \mathrm{SO}_{4}=1: 2: 1\right)$ and digested by heating until the perchloric acid was removed. After cooling, they were diluted with Milli-Q water and arsenic concentrations were determined by HG-AAS using a Shimadzu HVG-1 hydride generation system coupled to a Shimadzu AA680 atomic absorption spectrometer (Shimadzu, Kyoto, Japan).

TABLE 1

Trace element concentrations ( $\mu \mathrm{g} / \mathrm{g}$ dry wt.) in whole body of deep-sea fish from the Sulu Sea (November - December 2002)

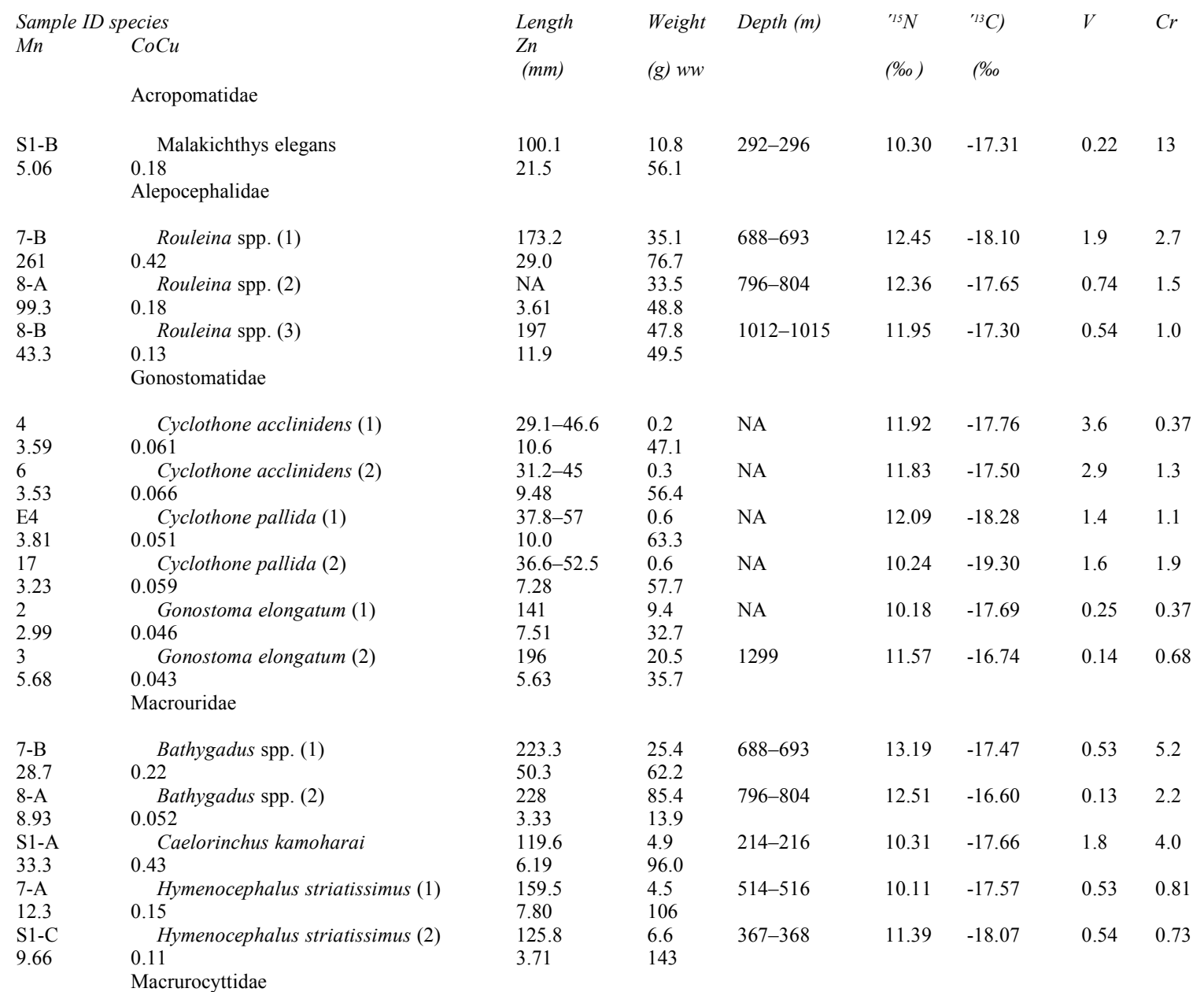




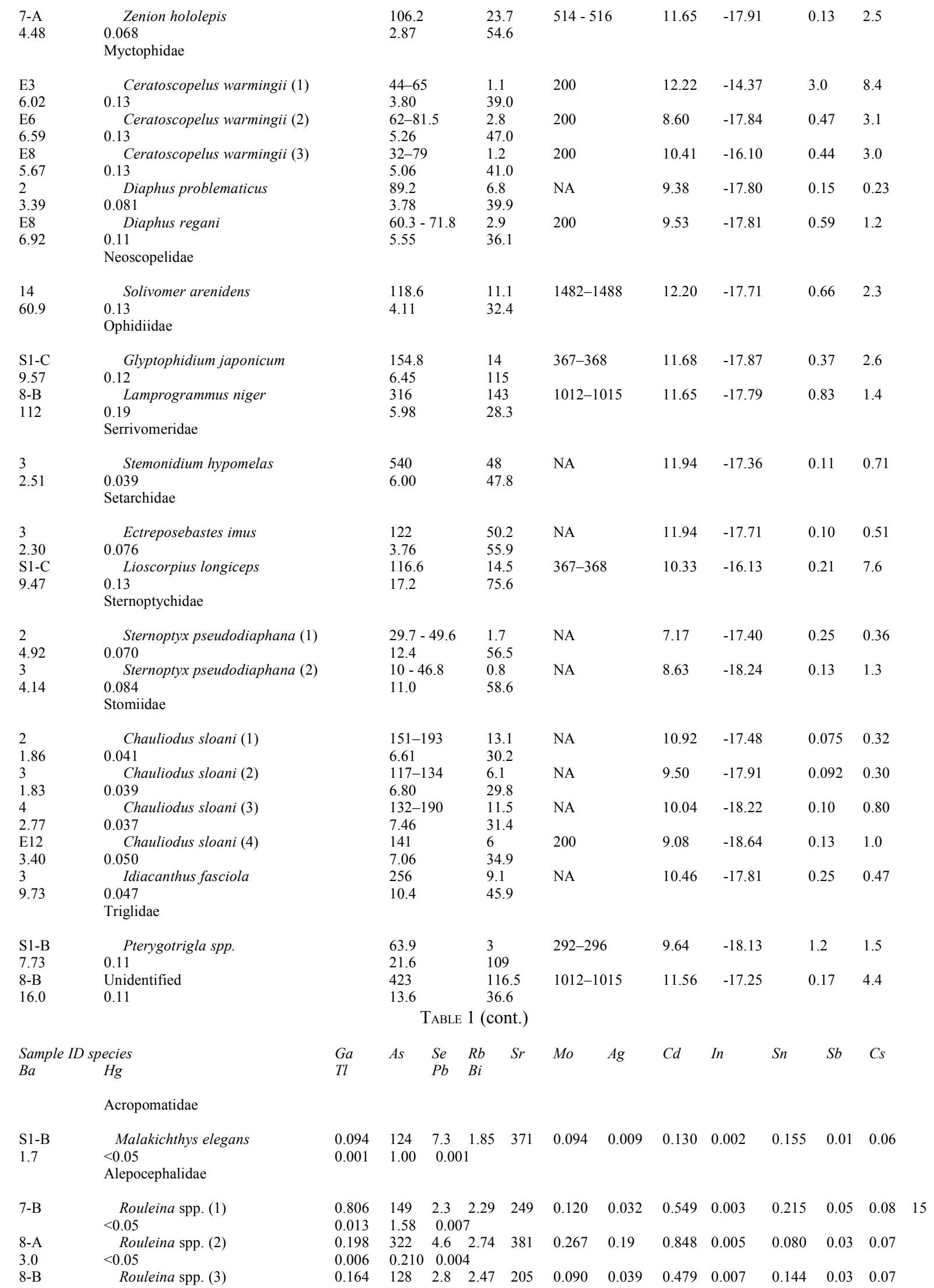




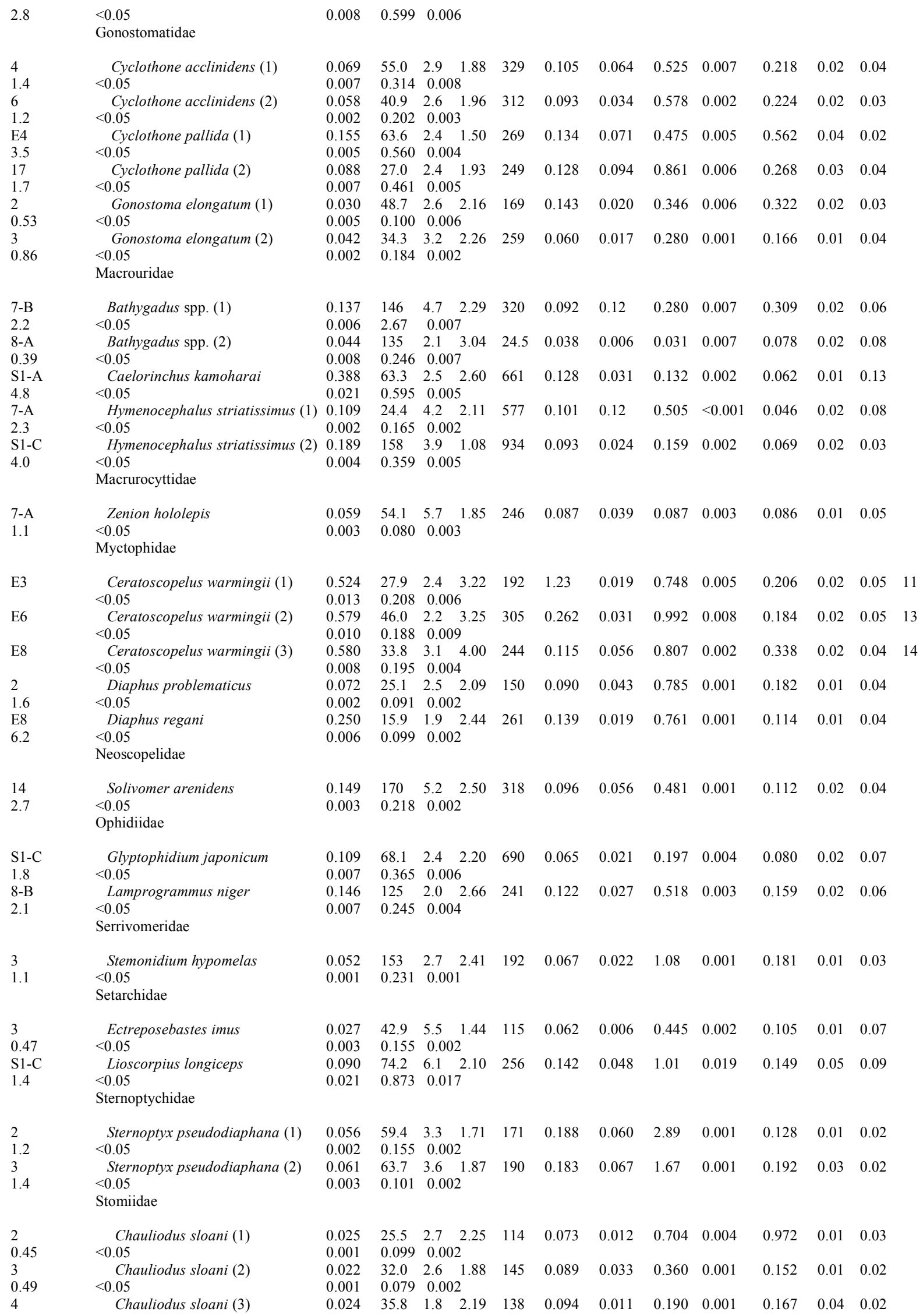




$\begin{array}{ll}0.46 & <0.05 \\ \mathrm{E} 12 & \text { Chauliodus sloani }(4) \\ 5.2 & <0.05 \\ 3 & \quad \text { Idiacanthus fasciola } \\ 0.59 & <0.05 \\ & \text { Triglidae } \\ & \quad \text { Pterygotrigla } \text { spp. } \\ \text { S1-B } & <0.05 \\ 3.3 & \text { Unidentified } \\ 8-\mathrm{B} & <0.05 \\ 0.98 & \\ & \text { NA }=\text { No available information }\end{array}$

Analytical quality was assessed using standard reference material DORM2 (Dogfish muscle; National Research Council, Canada). Recoveries of the elements ranged from $88 \%$ to $111 \%$ of the certified values. Concentrations of the trace elements were expressed on a dry weight basis $(\mu \mathrm{g} / \mathrm{g} \mathrm{dw})$. In order to compare values with published data reported on a wet weight basis, values were converted to wet weight basis assuming moisture content of $75 \%$.

\section{Stable isotopes analysis}

Sub samples from the homogenized samples were dried for $24 \mathrm{~h}$ at $60{ }^{\circ} \mathrm{C}$ and ground into powder with mortar and pestle. $1.0 \mathrm{mg}$ powder samples were packed into $4 \times 6 \mathrm{~mm}$ tin capsules for stable isotope measurements. Stable isotopes ratios of nitrogen and carbon were measured with a mass spectrometer (ANCAR-SL 20-20, Concern Ltd) coupled with an elemental analyzer. Isotopic ratios of carbon $\left(\delta^{13} \mathrm{C}\right)$ and nitrogen $\left(\delta^{15} \mathrm{~N}\right)$ were expressed as the deviation from standards in parts per thousand (\%o ) according to the following conventional formular (Doi et al., 2005):

$$
\begin{aligned}
& \delta^{13} \mathrm{C}, \delta^{15} \mathrm{~N}=\left[\left(\mathrm{R}_{\text {sample }} / \mathrm{R}_{\text {standard }}\right)-1\right] \times 1000(\% o), \\
& \text { where } \mathrm{R}={ }^{13} \mathrm{C} /{ }^{12} \mathrm{C} \text { or }{ }^{15} \mathrm{~N} /{ }^{14} \mathrm{~N}^{\circ}
\end{aligned}
$$

Atmospheric nitrogen and belemnite, Pee Dee Belemnite (PDB) were used as the isotope standards for nitrogen and carbon, respectively. The analytical precision for the isotope analysis was $\pm 0.2 \%$ for both $\mathrm{d}^{13} \mathrm{C}$ and $\mathrm{d}^{15} \mathrm{~N}$.

\section{Statistical analysis}

One-half of the value of the limit of detection of each element was substituted for those values below the limit of detection and applied in statistical analysis. Mann-Whitney $U$-test and Spearman's rank correlation coefficient were employed to measure the significance and correlation between trace element concentrations and stable isotope values. A $p$-value of less than 0.05 was considered to indicate statistical significance; all tests were two-tailed. Statistical analysis was performed using SPSS (version 12.0, SPSS Inc., Chicago, Il, USA) for Windows, 2003.

Trace element accumulation

\section{Results and discussion}

Concentrations of trace elements in the whole body of fish are shown in Table 1. Strontium was the most abundant element in the fish studied. The concentrations of $\mathrm{Sr}$ in this present study ranged from $24.5-934 \mu \mathrm{g} / \mathrm{g} \mathrm{dw}$ (the highest value in Hymenocephalus striatissimus) (Table 1). This trend was also observed in other studies of whole body fish species in the Manila Bay of the Philippines (Prudente et al., 1997) and the East China Sea (Asante, 2005). The high Sr 
concentrations stem from the fact that the whole body of fish was homogenized and, chemically, strontium resembles calcium, which is known to accumulate in bones (Nielsen, 1986).

Neither $\mathrm{Hg}$ nor $\mathrm{Pb}$ was at levels likely to cause concern if they were to be consumed by human beings. Waterman (1987) suggested that the maximum level of $\mathrm{Hg}$ should not exceed $0.5 \mu \mathrm{g} / \mathrm{g}$ wet weight (ww) of fish. Mercury concentrations in all the 36 fish samples were below the detection limit of $0.05 \mu \mathrm{g} / \mathrm{g} \mathrm{dw}(0.01 \mu \mathrm{g} / \mathrm{g} \mathrm{ww})$ (Table 1). Apart from the fact that the present specimens were smaller in size, mercury is generally known to accumulate with age. Mean $\mathrm{Hg}$ concentrations in commercial species of continental shelf are typically rather low (0.02-0.10 $\mu \mathrm{g} / \mathrm{g} \mathrm{ww}$ ) (Brown \& Balls, 1997), but there are marked exceptions, particularly among long-lived fish predators with concentrations of $1 \mu \mathrm{g} / \mathrm{g}$ ww or more (Topping \& Graham, 1977). Lead concentrations in the species examined were predominantly low with about $90 \%$ of the specimens having levels less than $1 \mu \mathrm{g} / \mathrm{g} \mathrm{dw}$. The highest $\mathrm{Pb}$ concentration of $2.67 \mu \mathrm{g} / \mathrm{g} \mathrm{dw}$ was found in Bathygadus spp.

Cadmium is toxic and, hence, elevated concentrations are a threat to marine biota. High $\mathrm{Cd}$ values encountered in some marine mammal species are diet related as a result of ingestion of cephalopods (Bustamante et al., 1998). Generally, concentrations of Cd were below $1 \mu \mathrm{g} / \mathrm{g} \mathrm{dw}$ except in Pterygotrigla spp., Sternoptyx pseudo-diaphana and Sternoptyx pseudodiaphana which had $4.29,2.89$ and $1.67 \mu \mathrm{g} / \mathrm{g} \mathrm{dw}$, respectively. Chromium concentrations in the $36 \mathrm{samples}$ ranged from $0.23-13 \mu \mathrm{g} / \mathrm{g} \mathrm{dw}$. The toxicity of $\mathrm{Cr}$ depends on the valency state of $\mathrm{Cr}$ in the compound (Merian, 1991; Mertz, 1987). Only 36\% of the 36 fish samples had below $1 \mu \mathrm{g} / \mathrm{g} \mathrm{dw}$ for Cr. Manganese concentrations were $261 \mu \mathrm{g} / \mathrm{g} \mathrm{dw}$ (Rouleina spp., $112 \mu \mathrm{g} / \mathrm{g} \mathrm{dw}$ (Lamprogrammus niger) and $99.3 \mu \mathrm{g} / \mathrm{g} \mathrm{dw}$ (Rouleina spp.) while the rest ranged from 1.83-43.3 $\mu \mathrm{g} / \mathrm{g} \mathrm{dw}$ (Table 1). Selenium concentrations ranged from 1.6-9.3 $\mu \mathrm{g} / \mathrm{g} \mathrm{dw}$. The highest concentration was found in Pterygotrigla spp..

The highest concentration of Zn detected was in Hymenocephalus striatissimus (143 $\mu \mathrm{g} / \mathrm{g} \mathrm{dw})$. On the other hand, the highest $\mathrm{Cu}$ concentration was found in Bathygadus spp. $(50.3 \mu \mathrm{g} / \mathrm{g} \mathrm{dw})$. Copper is essential for human health and its presence at these low levels could be considered desirable. Concentrations of Co ranged from $0.037-0.43 \mu \mathrm{g} / \mathrm{g} \mathrm{dw}$ with Caelorinchus kamoharai $(0.43 \mu \mathrm{g} / \mathrm{g} \mathrm{dw})$ and Rouleina spp. $(0.42 \mu \mathrm{g} / \mathrm{g} \mathrm{dw})$ having the maximum levels. The maximum $\mathrm{V}$ concen-tration of $3.6 \mu \mathrm{g} / \mathrm{g} \mathrm{dw}$ was found in Cyclothone acclinidens, followed closely by Ceratoscopelus warmingii $(3.0 \mu \mathrm{g} / \mathrm{g} \mathrm{dw})$. Rubidium and Ba were accumulated by all the fish analysed, with concentrations ranging from $1.08-4.00 \mu \mathrm{g} / \mathrm{g} \mathrm{dw}$ and $0.39-15 \mu \mathrm{g} / \mathrm{g} \mathrm{dw}$, respectively. The levels of $\mathrm{Bi}, \mathrm{Sb}, \mathrm{In}, \mathrm{Ag}, \mathrm{Mo}, \mathrm{Tl}$ and $\mathrm{Ga}$ were low and not detected in some samples. It could be that these elements are low in the waters and or the sediments of the Sulu Sea.

Rouleina, the only species belonging to the family Alepocephalidae, recorded the highest concentrations of $\mathrm{Mn}$ and $\mathrm{Ga}$, Lioscorpius longiceps belonging to the family Setarchidae, had the highest concentrations of $\mathrm{Bi}$ and In and Bathygadus spp., belonging to the family Macrouridae, showed the least concentration of Sr (Table 1). These variations among the species may be due to differences in metal assimilation and metabolic capacity, or may be indicative of species-specific accumulation.

\section{Vertical distribution of trace elements}

To understand the accumulation patterns of trace elements in relation to the habitation, the concentrations of trace elements were compared among habitation type of fish. The fish samples could be put into four groups on the basis of their habitation; mesopelagic, bathypelagic, shallow-demersal and deep-demersal. Higher concentrations of $\mathrm{Sr}, \mathrm{Zn}, \mathrm{Cu}, \mathrm{Se}$ and $\mathrm{Cd}$ in fish appeared in deep-demersal species (Fig. 2), suggesting the pattern of vertical distribution of these trace elements in the water column in the Sulu Sea. The mean concentrations of Sr, V, Co, Cs and Mn from this study were comparable with those of the Manila Bay, the Philippines (Fig. 3). 
While $\mathrm{Zn}$ and $\mathrm{Rb}$ concentrations were by a factor of half less than those of the Manila Bay, $\mathrm{Pb}$ and $\mathrm{Cu}$ concentrations were two times higher. However, it should be noted that background levels of trace elements in the marine environment can vary from region to region due to differences in local geology, and high contamination loads may, therefore, not be entirely due to increased loads of pollution.

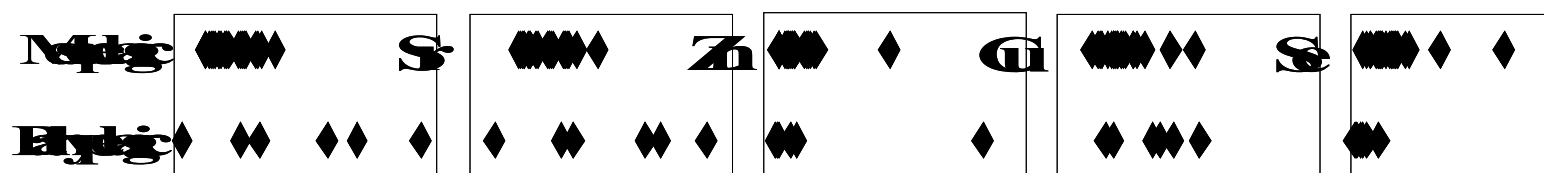

Fig. 2. Comparison of trace element concentrations in deep sea fish with their habitat from the Sulu Sea.

In general, concentrations of $\mathrm{Zn}$ and $\mathrm{Cu}$ from the Sulu Sea fish species were higher than fish from the North Lantau waters of Hong Kong (Fig. 3). Cadmium values from some fish samples from North Lantau waters of Hong Kong $(<0.9-23 \mu \mathrm{g} / \mathrm{g} \mathrm{dw})$ (Parsons, 1999a), were higher than those of the present specimens. However, there is an undeniably high degree of Cd pollution in Hong Kong (Parsons, 1999b). Comparing the results from this study to the dietary standards and guidelines for $\mathrm{Hg}, \mathrm{Pb}, \mathrm{Cu}$ and $\mathrm{Zn}$ in fish and shellfish of the Ministry of Agriculture, Fisheries and Food of the United Kingdom (MAFF, 2000), these levels were not high to warrant concern if they were to be consumed by humans (Fig. 3).

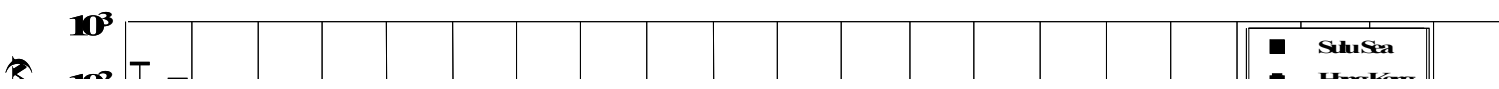

Fig. 3. Comparison of trace element concentrations (mean and range) in whole body of fish from Sulu Sea with studies in Hong Kong (Parsons, 1999a), Manila Bay (Prudente et al., 1997) and MAFF Guideline values (MAFF, 2000). NA = Not available, ND $=$ Not detected.

The general advisory limits for $\mathrm{Zn}$ and $\mathrm{Cu}$ in food are 50 and $20 \mu \mathrm{g} / \mathrm{g} w \mathrm{w}$, respectively (Kirk \& Sawyer, 1991). When the zinc and copper concentra-tions in this study were converted into 
wet weight basis using the respective moisture contents, the levels in all the 36 samples were below these advisory limits.

In Hong Kong, the allowable limit of $\mathrm{Pb}$ in fish tissue is $24 \mu \mathrm{g} / \mathrm{g} \mathrm{dw}$ (Parsons, 1999a) and considering this value, concentrations in all the 36 samples from the present study were low. Similarly, Cd concentrations were all below the $2 \mu \mathrm{g} / \mathrm{g}$ ww of safe Cd limit in seafood set by the Hong Kong Government (Parsons, 1998). However, 16.7\% of the 36 fish samples had high $\mathrm{Cr}$ concentrations (with the highest value of $13 \mu \mathrm{g} / \mathrm{g} \mathrm{dw}$ in Malakichthys elegans) when compared with Hong Kong's safe limit of $4 \mu \mathrm{g} / \mathrm{g}$ dw for $\mathrm{Cr}$ in sea food. This constitutes a health risk to humans as $\mathrm{Cr}$ is potentially toxic.

Stable isotopes $\left(\delta^{13} \mathrm{C}\right.$ and $\left.\delta^{15} \mathrm{~N}\right)$ analyses

A plot of $\delta^{15} \mathrm{~N}$ against $\delta^{13} \mathrm{C}$ for the analyzed fish species from the Sulu Sea is depicted in Fig. 4. The demersal fish species showed a relatively higher trophic level than the pelagic ones. The comparatively lower $\delta^{13} \mathrm{C}$ values of the pelagic species may suggest their coastal or pelagic source of food. Tables 2 and 3 show the calculated $r$ and $p$ values between trace element concentration and $\delta^{15} \mathrm{~N}$ and $\delta^{13} \mathrm{C}$ values, respectively. Elements with significant $p(<0.05)$ and $r$ values are shown in bold. Cadmium was not biomagnified as significant negative correlation $(p<$ $0.05)$ was observed with $\delta^{15} \mathrm{~N}$. This is in agreement with the fact that $\mathrm{Cd}$ is not biomagnified but diluted through trophic transfer. Copper, Mo, $\mathrm{Ag}$ and $\mathrm{Sn}$ also showed negative correlation with $\delta^{15} \mathrm{~N}$ though the correlations were not significant (Table 2). Manganese, Tl, $\mathrm{Pb}, \mathrm{Bi}, \mathrm{In}, \mathrm{Cs}$ and $\mathrm{As}$ showed significant positive correlation $(p<0.05)$ with $\delta^{15} \mathrm{~N}$ (Table 2, Fig. 5), suggesting that these elements were biomagnified. To our knowledge, this is the first study reporting $\mathrm{Tl}$ biomagnification in fish. The biomagni-fication observed for As is contrary to the assertion that As does not biomagnify in the food chain (Maher \& Butler, 1998; Eisler, 1994) but diluted by trophic transfer. This could be the first study reporting As biomagnification in fish, and further studies into this are required. Only $\mathrm{Rb}$ and $\mathrm{Cs}$ showed significant positive correlation with $\delta^{13} \mathrm{C}$ (Table 3, Fig. 6), implying that $\mathrm{Rb}$ and $\mathrm{Cs}$ mainly originated from oceanic source since oceanic plankton has high $\delta^{13} \mathrm{C}$.

TABLE 2

Correlation and significant values of trace element concentrations against ${ }^{15} \mathrm{~N}$ for all species from the Sulu Sea

$\begin{array}{lrr}\text { Element } & \text { r value } & \text { p value } \\ \mathrm{V} & 0.304 & 0.072 \\ \mathrm{Cr} & 0.282 & 0.096 \\ \mathrm{Mn} & 0.375 & 0.024 \\ \mathrm{Co} & 0.218 & 0.201 \\ \mathrm{Cu} & -0.135 & 0.434 \\ \mathrm{Zn} & 0.032 & 0.855 \\ \mathrm{Ga} & 0.107 & 0.534 \\ \mathrm{As} & 0.562 & <0.001 \\ \mathrm{Se} & 0.098 & 0.570 \\ \mathrm{Rb} & 0.260 & 0.126 \\ \mathrm{Sr} & 0.111 & 0.518 \\ \mathrm{Mo} & -0.281 & 0.097 \\ \mathrm{Ag} & -0.009 & 0.959 \\ \mathrm{Cd} & -0.340 & 0.042 \\ \mathrm{In} & 0.444 & 0.007 \\ \mathrm{Sn} & -0.002 & 0.990 \\ \mathrm{Sb} & 0.308 & 0.068 \\ \mathrm{Cs} & 0.388 & 0.019 \\ \mathrm{Ba} & 0.024 & 0.891\end{array}$




$\begin{array}{lll}\mathrm{TI} & 0.358 & 0.032 \\ \mathrm{~Pb} & 0.335 & 0.046 \\ \mathrm{Bi} & 0.3412 & 0.013 \\ & \text { TABLE } 3 & \end{array}$

Correlation and significant values of trace element concentrations against $\delta^{13} \mathrm{C}$ for all species from the Sulu Sea

$\begin{array}{lrr}\text { Element } & \text { r value } & \text { p value } \\ \mathrm{V} & -0.057 & 0.740 \\ \mathrm{Cr} & 0.230 & 0.178 \\ \mathrm{Mn} & 0.193 & 0.259 \\ \mathrm{Co} & 0.222 & 0.193 \\ \mathrm{Cu} & -0.035 & 0.841 \\ \mathrm{Zn} & 0.188 & 0.272 \\ \mathrm{Ga} & 0.062 & 0.721 \\ \mathrm{As} & 0.137 & 0.425 \\ \mathrm{Se} & 0.293 & 0.083 \\ \mathrm{Rb} & 0.342 & 0.041 \\ \mathrm{Sr} & 0.116 & 0.502 \\ \mathrm{Mo} & -0.152 & 0.377 \\ \mathrm{Ag} & -0.183 & 0.285 \\ \mathrm{Cd} & -0.028 & 0.870 \\ \mathrm{In} & 0.225 & 0.188 \\ \mathrm{Sn} & -0.088 & 0.611 \\ \mathrm{Sb} & 0.153 & 0.374 \\ \mathrm{Cs} & 0.359 & 0.032 \\ \mathrm{Ba} & 0.155 & 0.367 \\ \mathrm{TI} & 0.206 & 0.228 \\ \mathrm{~Pb} & 0.028 & 0.869 \\ \mathrm{Bi} & 0.174 & 0.310\end{array}$




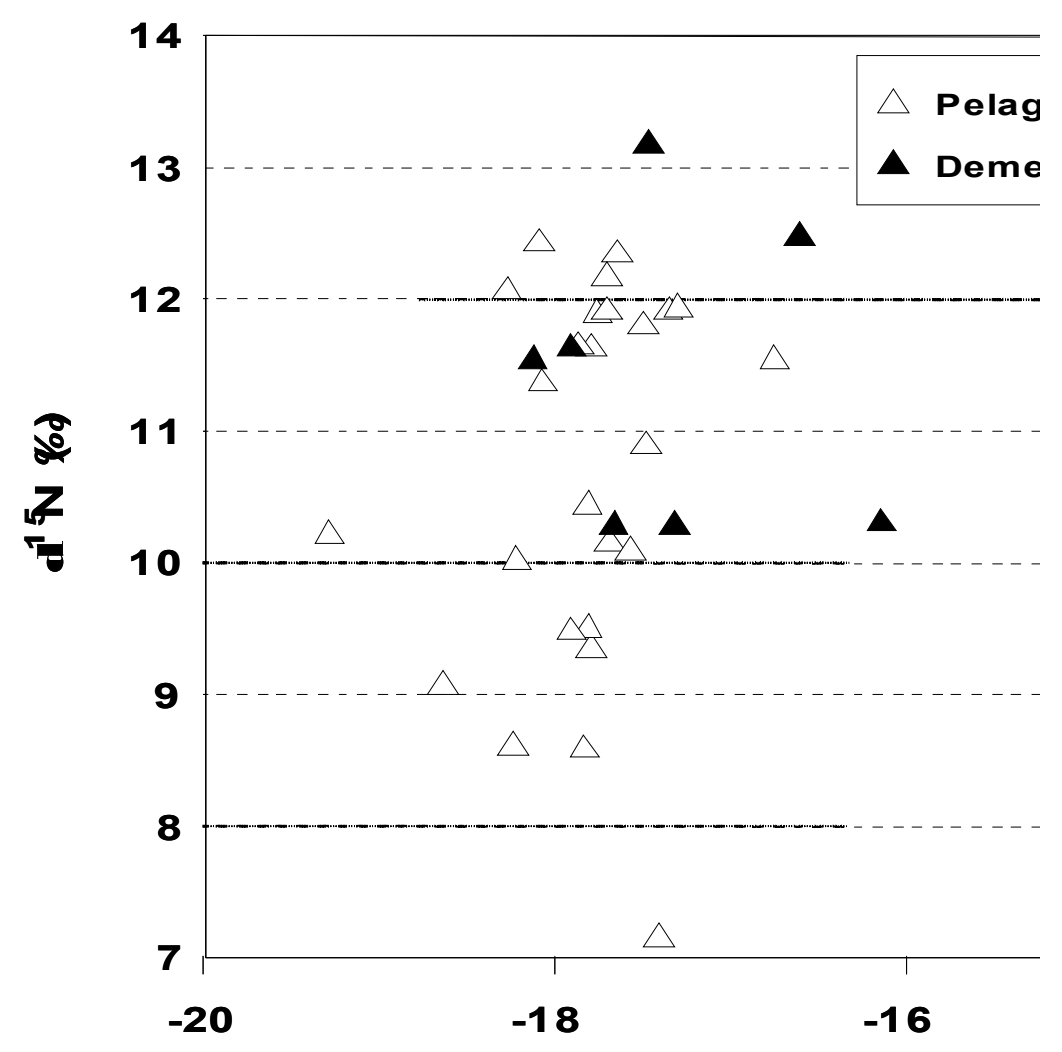

Fig. 4. $\delta^{15} \mathrm{~N}$ and $\delta^{13} \mathrm{C}$ stable isotope plot of all analyzed species from the Sulu Sea.
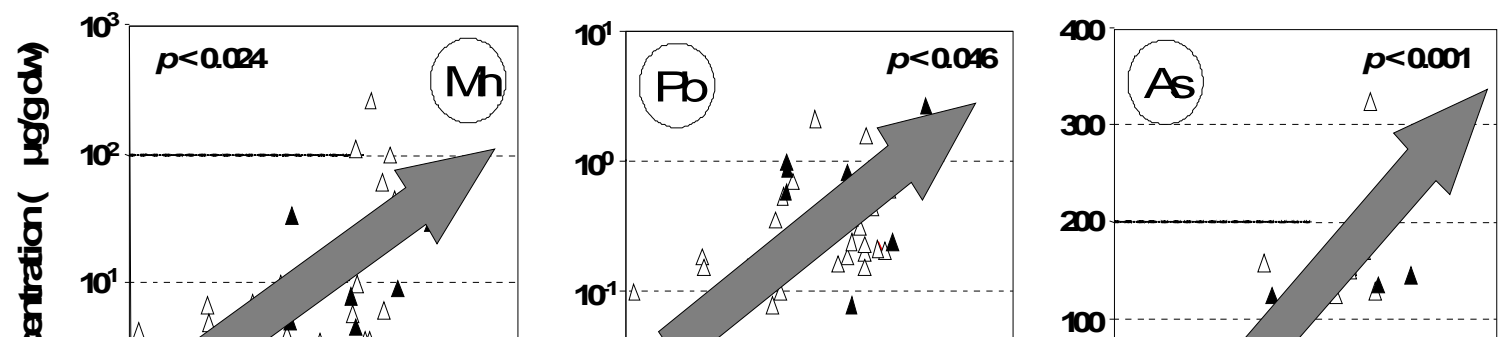

Fig. 5. Correlation between $\mathrm{Mn}, \mathrm{Pb}$ and $\mathrm{As}$ concentrations and $\mathrm{a}^{15} \mathrm{~N}$ for all analyzed species from the Sulu Sea.

\section{Conclusion}

The study has provided information on the contamina-tion status of trace elements in deep sea fish from the Sulu Sea. The variations of trace elements among the species may be due to 
differences in metal assimilation and metabolic capacity or may be indicative of species-specific accumula-tion. Strontium was the most abundant element in the fish studied. The high $\mathrm{Sr}$ concentrations stem from the fact that the whole body of fish was homogenized and, chemically, strontium resembles calcium, which is known to accumulate in bones and hard tissues. Higher concentrations of $\mathrm{Sr}, \mathrm{Zn}, \mathrm{Cu}, \mathrm{Se}$ and $\mathrm{Cd}$ in fish appeared in deep-demersal species, suggesting the pattern of vertical distribution of these trace elements in the water column in the Sulu Sea.

Manganese, $\mathrm{Tl}, \mathrm{Pb}, \mathrm{Bi}, \mathrm{In}, \mathrm{Cs}$ and As showed significant positive correlation $(p<0.05)$ with $\mathrm{d}^{15} \mathrm{~N}$, suggesting that these elements were biomagnified. Rubidium and Cs showed significant positive correlation with $\mathrm{d}^{13} \mathrm{C}$, implying that $\mathrm{Rb}$ and $\mathrm{Cs}$ would originate from offshore waters as oceanic plankton has high $\mathrm{d}^{13} \mathrm{C}$.

Comparing results from this study to the dietary standards and guidelines for $\mathrm{Hg}, \mathrm{Pb}, \mathrm{Cu}$ and $\mathrm{Zn}$ in fish and shellfish for the Ministry of Agriculture, Fisheries and Food, UK, these levels were not high to warrant concern if they were to be consumed by humans. Although the sample sizes in this study were limited, the trace element concentrations found suggest that anthropogenic loading of toxic elements such as $\mathrm{Hg}, \mathrm{Cd}$ and $\mathrm{Pb}$ to the Sulu Sea is relatively low. It may be inferred that fish from the Sulu Sea are not adversely affected by these toxicants and pose no risk for human health. However, $16.7 \%$ of the 36 fish samples had high $\mathrm{Cr}$ concentrations when compared with Hong Kong's safe limit of $4 \mu \mathrm{g} / \mathrm{g} \mathrm{dw}$ for $\mathrm{Cr}$ in sea food. This constitutes a health risk to humans, as $\mathrm{Cr}$ is potentially toxic.

\section{Acknowledgement}

The authors wish to express their profound gratitude to the officers and crew members of the Hakuho Maru of the Ocean Research Institute, University of Tokyo, for collecting the samples. This study was supported by grants from 21st Century Center of Excellence (COE) Program and Grant-in-Aid for Creative Basic Research from the Ministry of Education, Culture, Sports, Science and Technology, Japan.

\section{References}

Asante K. A. (2005). Distribution of trace elements in the environment - case studies in the East China Sea and Ghana. (Masters Thesis.) Ehime University, Japan. 120 pp.

BAS (Bureau of Agricultural Statistics) (2004). Fisheries Statistics of the Philippines 2001-2003. Vol. 12.

Briones M., Dey M. M. and Ahmed M. (2004). The future for fish in the food and livlihoods of the poor in Asia. $N A G A$, WorldFish Center Q. 27(3 \& 4): July to December.

Bustamante P., Caurant F., Fowler S. W. and Miramand P. (1998). Cephalopods as a vector for the transfer of cadmium to top marine predators in the North-East Atlantic ocean. Sci. tot. Envir. 220: 71-80.

Cronin M., Davies, I. M., Newton A., Pirie, J. M., Graham, T. and Swan, S. (1998). Trace metal concentrations in deep sea fish from the North Atlantic Mar. envir. Res. 45: 225-238.

Das K., Beans C., Holsbeek L., Mauger G., Berrow S. D., Rogan E. and Bouquegneau J. M. (2003). Marine mammals from the Northeast Atlantic: evaluation of their trophic position by ${ }^{{ }^{13} \mathrm{C} \text { and }}{ }^{15} \mathrm{~N}$ measurements and influence on their trace metals concentrations. Mar. envir. Res. 56: 349-365.

Dauby P., Khomsi A. and Bouquegneau J. M. (1998). Trophic relationships within intertidal communities of the Brittany coasts: a stable carbon isotope analysis. J. Coast. Res. 14: 1202-1212.

DeNiro M. J. and Epstein S. (1978). Influence of the diet on the distribution of carbon isotopes in animals. Geochim. cosmochim. Acta 42: 495-506.

DeNiro M. J. and Epstein S. (1981). Influence of the diet on the distribution of nitrogen isotopes in animals. Geochim. cosmochim. Acta 45: 341-351.

Doi H., Matsumasa M., Toya T., Satoh N., Mizota. C., Maki Y. and Kikuchi E. (2005). Spatial shifts in food sources for macrozoobenthos in an estuarine ecosystem: Carbon and nitrogen stable isotope analyses. Estuar. coast. Earth Sci. 64: 316-322.

Eisler R. (1994). A review of arsenic hazards to plants and animals with emphasis on fishery and wildlife resources. In Arsenic in the Environment, Part II: Human Health and Ecosystem Effects. (J. O. Nriagu, ed.), pp.185-259. John Wiley, New York. 
Gordon J. D. M., Merrett N. R. and Haedrich R. L. (1995). Environmental and biological aspects of slope dwelling fishes of the North Atlantic. In Deep-water Fisheries of the North Atlantic Oceanic Slope, (A.G. Hooper, ed.), pp.1-26. Kluwer, The Netherlands.

Hobson K. A. and Welch H. E. (1992). Determination of trophic relationships within a high Artic food web using $\delta^{13} \mathrm{C}$ and $\delta^{15} \mathrm{~N}$ analysis. Mar. Ecol. Prog. Ser 84: 9-18.

Hobson K. A., Ambrose W. G. and Renaud P. E. (1995). Sources of primary production, benthic-pelagic coupling, and trophic relationships within the North-east water polynia: insights from $\mathrm{d}^{13} \mathrm{C}$ and $\mathrm{d}^{15} \mathrm{~N}$ analysis. Mar. Ecol. Prog. Ser. 128: 1-10.

Hobson K. A., Sease J. L., Merrick R. L. and Piatt J. F. (1997). Investigating trophic relationships of pinnipeds in Alaska and Washington using stable isotopes ratios of nitrogen and carbon. Mar. Mam. Sci 13: 114-132.

Kirk R. S. and Sawyer R. (1991). Pearson's composition and analysis of food. London.

Luna C. Z., Silvestre G. T., Green S. J., Carreon M. F. and White A. T. (2004). Profiling the status of Philippine marine fisheries: A general introduction and overview. In Turbulent seas: The status of Philippine marine fisheries. Coastal Resource Management Project, Cebu City, Philippines. 378 pp.

MAFF (Ministry of Agriculture, Fisheries and Food) (2000). Monitoring and surveillance of non-radioactive contaminants in the aquatic environment and activities regulating the disposal of wastes at sea, 1997. In Aquatic Environment Monitoring Report No. 52. Center for Environment, Fisheries and Aquaculture Science, Lowestoft, UK.

Maher W. and Butler E. (1998). Arsenic in the marine environment. Appl. Organometal. Chem. 2: 191-214.

Merian E. (1991). Trace metals and their compounds in the environment. VCH Publishers, Weinheim, Germany.

Mertz W. (1987). Trace metals in human and animal nutrition. Academic Press, Florida, USA.

Mormede S. and Davies I. M. (2001). Heavy metal concentrations in commercial deep-sea fish from the Rockall Trough. Contin. Shelf Res. 21: 899-916.

Nielsen F. H. (1986). Other elements. In Trace Elements in Human and Animal Nutrition. (W. Mertz, ed.), pp.415463. Academic, San Diego, CA, USA.

Nishida S. and Gamo T. (eds.) (2004) Preliminary Report of the Hakuho-Maru Cruise KH-02-4. Ocean Research Institute, University of Tokyo.

Parsons E. C. M. (1998). Trace metal levels in decapod crustaceans from North Lantau waters, Hong Kong. In The Marine Biology of the South China Sea. (B. Morton, ed.), pp. 411-422. Hong Kong University Press, Hong Kong.

Parsons E. C. M. (1999a). Trace element concen-trations in whole fish from North Lantau waters, Hong Kong. ICES J. Mar. Sci. 56(5): 791-794.

Parsons E. C. M. (1999b). Trace element concentrations in the tissues of cetaceans from Hong Kong's territorial waters. Envir. Conserv. 26(1): 30-40.

Prudente M., Kim E., Tanabe S. and Tatsukawa R. (1997). Metal levels in some commercial fish species from Manila Bay, the Philippines. Mar. Pollu. Bull 34(8): 671-674.

Ruhl H. A. and Smith Jr K. L. (2004). Shifts in deep-sea community structure linked to climate and food supply. Science 305: 513-515.

Tatsukawa R. and Tanabe S. (1984). Environmental monitoring: geochemical and biochemical behaviour of PCB's in the open ocean environment. Proceedings of PCB-seminar. (M. C. Barrors, H. Konemann and R. Visser, ed.), pp. 99-118. Ministry of Housing and Ministry of Agriculture and Fisheries, The Netherlands.

Topping G. and Graham W. C. (1977). ICES Fisheries Improvement Committee, E: 39.

Vas P., Gordon J. D. M., Fielden P. R. and Overnell J. (1993). The trace metal ecology of ichthyofauna in the Rockall Trough, north-eastern Atlantic. Mar. Pollu. Bull. 26(11): 607-612.

Waterman J. J. (1987) Composition and quality of fish: a dictionary. Torry research note No. 87, Torry Research Station, Aberdeen.

Watling H. R. (1983). Accumulation of seven metals by Crassostrea gigas, C. margaritacea, Perna perna and Chromytillus meridionalis. Bull. envir. Contamin. Technol. 30: 313-320.

Windom H., Stein D., Sheldon R. and Smith R. (1987). Comparison of trace metal concentrations in muscle tissue of a benthopelagic fish (Coryphaenoides armatus) from the Atlantic and Pacific Oceans. Deep Sea Res. Part A. 34(2): 213-220. 